DOI 10.15290/cnisk.2017.02.03.08

DR DIANA DAJNOWICZ-PIESIECKA

orcid.org/0000-0003-1609-8463

Uniwersytet $w$ Białymstoku

\title{
Rola kobiet przy porwaniach rodzicielskich w świetle wyników badań aktowych. Sprawczynie czy pokrzywdzone przestępstwem ? ${ }^{1}$
}

\section{Streszczenie}

We wszystkich państwach świata kobiety znacznie rzadziej popełniaja przestępstwa. Niniejsze opracowanie ma na celu weryfikacje tego twierdzenia na gruncie przestępstwa porwania rodzicielskiego, czyli takiego porwania dziecka, którego dokonuje jego matka bądź ojciec. Artykuł przedstawia informacje o tym, czy kobiety w kontekście porwań rodzicielskich są częściej osobami pokrzywdzonymi, czy raczej sprawczyniami tego typu czynu zabronionego, jak również prezentuje wybrane sytuacje faktyczne opisane na podstawie poddanych badaniu aktowemu spraw karnych o przestępstwo określone w art. 211 Kodeksu karnego.

Słowa kluczowe: porwania rodzicielskie, sprawca przestępstwa, małoletni, rodzice, przestępstwa przeciwko rodzinie i opiece

\footnotetext{
1 Artykuł powstał na podstawie wyników projektu pt. „Porwania rodzicielskie w świetle polskiego orzecznictwa karnego - aspekty prawne i kryminologiczne” (nr rej. 2014/15/N/HS5/02688) finansowanego przez Narodowe Centrum Nauki. Projekt zrealizowany pod opieka naukowa prof. zw. dr. hab. Emila W. Pływaczewskiego na Wydziale Prawa Uniwersytetu w Białymstoku przez kierownika projektu dr. Dianę Dajnowicz-Piesiecką.
} 


\title{
THE ROLE OF WOMEN IN PARENTAL CHILD ABDUCTIONS IN THE LIGHT OF THE EXAMINATION OF RECORDS. PERPETRATORS OR VICTIMS OF AN OFFENCE?
}

\begin{abstract}
In all countries all over the world the world, women are less likely to commit crime than men. The following study aims at verifying this assertion on the grounds of the criminal offense of child abduction, which is understood as the abduction of a child by his mother or father. The article provides information on whether women, in the context of parental abductions, are more likely to be victims rather than perpetrators of this type of offense. It discusses selected factual situations described on the basis of criminal cases referred to in Art. 211 of the Criminal Code.
\end{abstract}

Keywords: parental abductions, perpetrators, minors, parents, crime against the family and care

\section{Wprowadzenie}

Występek uprowadzenia lub zatrzymania małoletniego poniżej 15. roku życia lub osoby nieporadnej, które ustawodawca sprecyzował w art. 211 Kodeksu karnego ${ }^{2}$, stanowi przestępstwo powszechne. Oznacza to, iż jego podmiotem (czyli osoba, która je popełnia) może być każdy, kto po osiagnieciu określonego wieku odpowiedzialności karnej uprowadził lub zatrzymał małoletniego bądź osobę nieporadna wbrew woli powołanego do opieki albo nadzoru ${ }^{3}$.

Jednak w świetle wyników badań kryminologicznych nad przedmiotowym występkiem najczęściej sprawcami tego typu zachowania przestępnego sa rodzice porywanych małoletnich oraz inne osoby najbliższe tym dzieciom. Potwierdzenie tej tezy znaleźć

Ustawa z dnia 6 czerwca 1997 r. - Kodeks karny, Dz.U. z 2016 r. poz. 1137 t.j.

3 R.A. Stefański, Prawo karne materialne część szczególna, Warszawa 2009, s. 293; M. Bojarski [w:] Prawo karne materialne. Część ogólna i szczególna, red. M. Bojarski, Warszawa 2015, s. 509; S. Hypś [w:] Prawo karne, red. A. Grześkowiak, K. Wiak, Warszawa 2015, s. 371. 
można w wynikach prac badawczych Katarzyny Drapały i Konrada Buczkowskiego, którzy ustalili, że większość uprowadzeń lub zatrzymań dzieci dokonują ich rodzice ${ }^{4}$. Również Helena Kołakowska-Przełomiec ujawniła podobną tendencję, $z$ tą jednak różnica, iż według jej ustaleń najczęściej sprawca przestępstwa porwania dziecka jest jego ojciec, a incydentalnie tylko zachowania takiego dopuszcza się osoba obca ${ }^{5}$.

Tym samym stwierdzić należy, że wśród przestępstw porwania małoletniego dominuja porwania rodzicielskie, czyli taki rodzaj uprowadzenia lub zatrzymania dziecka, którego sprawca jest matka bądź ojciec małoletniego. Warto w tym kontekście zwrócić uwagę, że badania Kołakowskiej-Przełomiec ujawniły, iż wśród rodziców-porywaczy dominują ojcowie. Chociaż wniosek taki wpisuje się w powszechnie podnoszone twierdzenie, że mężczyźni są częściej sprawcami przestępstw niż kobiety ${ }^{6}$, autorka przedkładanego tekstu za istotne uznała zweryfikowanie, czy ten ogólny trend znajdzie swoje odzwierciedlenie także w wynikach jej badań aktowych i czy rzeczywiście to częściej matki porywanych dzieci sa pokrzywdzonymi przestępstwem określonym w art. $211 \mathrm{k} . \mathrm{k}$. Dlatego też głównym celem niniejszego artykułu jest wyjaśnienie, czy rzeczywiście w obszarze porwań rodzicielskich kobiety sa przeważnie pokrzywdzonymi, nie zaś sprawcami przestępstwa. Wypowiedź $\mathrm{w}$ tym zakresie uzupełniono wybranymi analizami przypadków porwań rodzicielskich, w których kobiety występowały bądź jako sprawczynie porwania, bądź jako pokrzywdzone. Opisy studiów przypadków umożliwiają bowiem poznanie okoliczności i przyczyn porwań rodzicielskich, w których kobiety pełniły rolę albo ofiary bezprawnego zachowania, albo były tych zachowań autorkami.

\footnotetext{
${ }_{4}$ K. Drapała, K. Buczkowski, Porwania rodzicielskie. Analiza umorzeń i odmów wszczęcia postępowania $w$ sprawach o przestępstwo $z$ art. 211 k.k., „Prawo w działaniu" 2014, t. 18, s. 105-132.

5 H. Kołakowska-Przełomiec, Przestęstwa przeciwko rodzinie i opiece $w$ projekcie kodeksu karnego, „Przegląd Prawa Karnego” 1995, nr 12, s. 58.

6 Szerzej o danych liczbowych zob. Udział kobiet w ogólnej liczbie poszczególnych rodzajów przestępstw, [Dostęp: 1.09.2017]. Dostępny w World Wide Web: $<$ http://bit.ly/2hL5QZ0>.
} 


\section{Metodyka badań}

Niniejszy artykuł powstał w oparciu o fragment wyników badań aktowych spraw karnych rozpoznanych na podstawie kwalifikacji prawnej $z$ art. 211 k.k. Sprawy, które stanowiły przedmiot analiz, zostały rozpoznane w okresie od 1 września 1998 r. do 31 grudnia 2014 r. w 36 sąach rejonowych mieszczacych się w osiemnastu polskich miastach wojewódzkich. Dobór obszaru badawczego wynikł $z$ informacji udzielonej przez Krajowy Rejestr Karny, iż w Polsce od 1 września 1998 r. do 31 grudnia 2014 r. rozpoznano w sumie 362 sprawy karne o czyn $z$ art. 211 k.k., wśród których aż $99(27,5 \%)$ rozpoznano właśnie w sądach mieszczących się w miastach wojewódzkich. Sąów rejonowych w miastach wojewódzkich ustalono natomiast 36 i stanowią one $11 \%$ wszystkich 321 sądów rejonowych w Polsce. Ze względu na to, że blisko jedna trzecia spraw o porwanie dziecka została rozpoznana w ponad jednej dziesiątej wszystkich polskich sądów rejonowych, w badaniach pominięto te jednostki sądowe, w których spraw na podstawie art. $211 \mathrm{k} . \mathrm{k}$. rozpoznano mniej.

Informacja, że blisko $30 \%$ spraw sądowych o czyn $z$ art. 211 k.k. rozpoznano w samych tylko sądach rejonowych w miastach wojewódzkich, była podstawa stwierdzenia, że taka próba będzie dostateczna do uzyskania szerokiego spektrum wiadomości o porwaniach rodzicielskich w dwuletnim okresie samodzielnej realizacji projektu naukowego pt. Porwania rodzicielskie $w$ świetle polskiego orzecznictwa karnego - aspekty prawne $i \mathrm{kry}$ minologiczne, finansowanego ze środków NCN. Dobór próby był bowiem zdeterminowany założeniami grantowymi, które przewidywały samodzielność w realizacji kwerend badawczych i opracowywania pozyskanego materiału. Realizacja badań aktowych podlegała również ograniczeniu czasowemu, projekt bowiem trwał 24 miesiące.

Badanie aktowe dotyczyło spraw o przestępstwo określone w art. 211 k.k., w których sprawca uprowadzenia lub zatrzymania małoletniego był jego rodzic (bądź też oboje rodziców). Na podstawie danych $z$ Krajowego Rejestru Karnego ustalono, że w sądach objętych badaniem w latach 1998-2014 na podstawie art. 211 k.k. 
rozpoznano w sumie 99 spraw, ostatecznie jednak do analizy zakwalifikowano 59 spraw - tyle $z$ nich bowiem dotyczyło porwań rodzicielskich. W pozostałych czterdziestu sprawach sprawcami nie byli rodzice małoletnich, lecz inne osoby - głównie osoby najbliższe $z$ rodziny porwanego dziecka, znacznie rzadziej osoby całkowicie obce. Tych 59 ustalonych spraw o porwania rodzicielskie stanowiło całość dostępnego materiału aktowego dotyczącego przedmiotowego przestępstwa.

Posłużenie się metodą badań aktowych podyktowane było tym, że akta spraw sądowych cechuja się wysoka wartością poznawczą. Ukazuja faktyczny stan funkcjonowania instytucji stosujacych prawo oraz dostarczaja informacji o zdarzeniach, które poddawane sa regulacjom prawnym.

Badania aktowe przeprowadzono przy zastosowaniu metod ilościowych i jakościowych. Wykorzystano technikę badawcza ankietowania, zaś narzędziem badawczym był autorski kwestionariusz ankiety. Funkcje respondenta $\mathrm{w}$ badaniach pełniły akta spraw karnych o występki określone w art. 211 k.k., tj. uprowadzenie lub zatrzymanie małoletniego.

W narzędziu badawczym sformułowano siedemnaście pytań otwartych i 95 pytań, które zostały wykorzystane do celów analizy jakościowej i ilościowej. Pytania zawarte w kwestionariuszu ankiety podzielono na siedem głównych bloków tematycznych dotyczących informacji ogólnych o: sprawie, sprawcy, pokrzywdzonym, porwanym małoletnim, czynie przestępnym, którego dopuścił się sprawca, dowodach w sprawie oraz informacji dotyczacych postępowania sadowego. Na podstawie odpowiedzi udzielonych na pytania przede wszystkim $z$ bloków tematycznych dotyczących sprawcy i pokrzywdzonego powstał przedłożony artykuł.

\section{Wyniki badań aktowych}

Do badań aktowych wybrano 59 spraw karnych, należy jednak wskazać, że nie każda sprawę sądową wieńczyło ustalenie, iż oskarżony rzeczywiście był sprawca zarzucanego mu czynu. Informacje na temat sprawców przestępstwa odnaleziono w 51 spra- 
wach, w których wydano wyroki skazujące (39 spraw) lub warunkowo umarzające postępowanie karne (dwanaście spraw) ${ }^{7}$. W pozostałych ośmiu sprawach sądy wydały trzy wyroki umarzające postępowanie karne bezwarunkowo, jeden wyrok uniewinniający oraz cztery postanowienia o umorzeniu postępowania.

We wspomnianych 51 sprawach, które zakończyły się uznaniem oskarżonej osoby za sprawcę przestępstwa, potwierdzono sprawstwo 55 osób. Rozbieżność pomiędzy liczba spraw sądowych a liczba ustalonych sprawców wynikła $z$ tego, że w czterech sprawach poddanych badaniu o popełnienie przestępstwa określonego w art. 211 k.k. oskarżono więcej niż jedną osobę, a konkretniej oboje rodziców, których dzieci z pewnych przyczyn znajdowały się pod opieką innych osób lub podmiotów niżeli matka czy ojciec.

Chcąc się dowiedzieć, czy porwań rodzicielskich częściej dopuszczali się matki, czy ojcowie uprowadzanych lub zatrzymywanych małoletnich, w badanych aktach spraw sadowych poszukiwano informacji na temat płci sprawców przedmiotowego przestępstwa. Informacje w tym zakresie przedstawiono na poniższym wykresie.

Wykres 1. Płeć sprawców

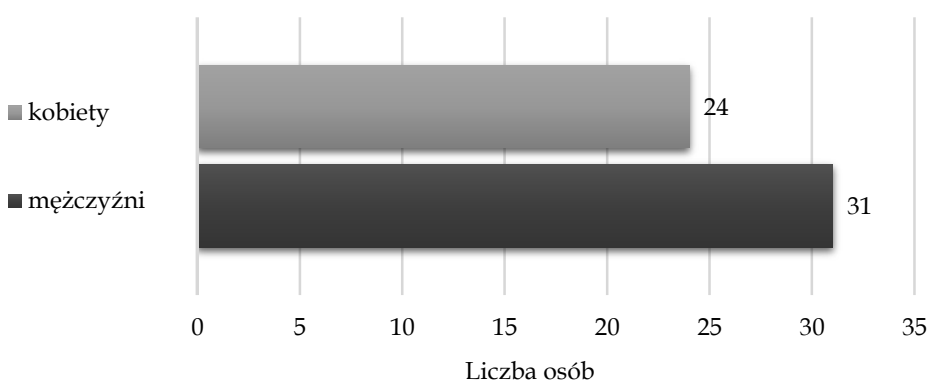

Źródło: opracowanie własne.

\footnotetext{
7 Poszukując wiadomości o sprawcach przestępstwa określonego w art. $211 \mathrm{k.k}$, brano pod uwage sprawy, w których zapadły wyroki skazujace lub wyroki warunkowo umarzajace postępowanie, ponieważ przyjęto za A. Markiem i V. Konarska-Wrzosek, iż istota warunkowego umorzenia postępowania tyczy się właśnie takiej osoby, którą sąd uznał za sprawcę przestępstwa, dopatrzył się jej winy w jego popełnieniu, jednocześnie jednak zdecydował się odstapić od skazania i kary. A. Marek, V. Konarska-Wrzosek, Prawo karne, Warszawa 2016, s. 310.
} 
Jak wynika $z$ powyższego wykresu, ustalona na podstawie statystyk kryminalnych, badań typu self-report oraz badań witalizacyjnych tendencja, iż udział kobiet i mężczyzn w popełnianiu przestępstw jest zróżnicowany, bowiem kobiety popełniają mniej przestępstw niż mężczyźni ${ }^{8}$, potwierdziła się w odniesieniu do porwań rodzicielskich. W 51 poddanych analizie sprawach sadowych ujawniono 55 sprawców przestępstwa porwania rodzicielskiego, wśród których większość stanowili mężczyźni. Należy jednak zwrócić uwagę, że przewaga liczby mężczyzn nad liczba kobiet nie była znaczna. $Z$ powyższego wykresu wynika bowiem, że 31 mężczyzn było sprawcami porwania rodzicielskiego. Tym samym stwierdzić należy, iż ojcowie małoletnich stanowili $56 \%$ sprawców porwania rodzicielskiego. Kobiet, które uprowadziły lub zatrzymały swoje dziecko, ustalono natomiast 24 i stanowiły one 44\% wszystkich ujawnionych sprawców.

W badanych sprawach przedmiot rozpoznania stanowiły zarówno zachowania kobiet, które były sprawczyniami czynu określonego w art. 211 k.k. i porywały swoje dzieci, jak i zachowania mężczyzn, którzy, będąc sprawcami porwania dziecka, zabierali je spod opieki matek. Chcąc poznać okoliczności i przyczyny porwań rodzicielskich, w których kobiety pełniły rolę albo osoby pokrzywdzonej, albo sprawcy, przytoczyć należy stany faktyczne poszczególnych spraw, które poddano analizie aktowej.

Jedna ze spraw, w których kobieta była sprawca porwania rodzicielskiego, była przedmiotem rozpoznania w Sązie Rejonowym w Gorzowie Wielkopolskim w 2014 r. ${ }^{9} \mathrm{~W}$ sprawie tej sprawczyni dokonała zatrzymania swojej małoletniej córki wbrew woli ojca dziecka, który był powołany do sprawowania nad dzieckiem opieki. Mężczyzna od 2006 r. był rozwiedziony ze sprawczynia porwania rodzicielskiego. W wyroku rozwodowym sąd powierzył wykonywanie władzy rodzicielskiej nad małoletnimi dziećmi stron (synem urodzonym w 1997 r. i córką urodzoną w 2000 r.) ich ojcu, ograni-

8 J. Błachut, Płeć a przestępczość [w:] Nauka wobec przestępczości. Ksiega ku czci prof. T. Hanauska, red. J. Błachut, M. Szewczyk, J. Wójcikiewicz, Kraków 2001, s. 163.

9 Sprawa o sygn. II K 199/14. 
czając władzę rodzicielska sprawczyni do prawa współdecydowania o istotnych sprawach dzieci (np. miejsca zamieszkania, wyjazdów za granicę, kierunku kształcenia, sposobu i miejsca leczenia).

Są w wyroku rozwodowym ustalił też sposób utrzymywania przez sprawczynię kontaktów $z$ dziećmi, umożliwiając jej spotykanie się $z$ małoletnimi i zabieranie ich $z$ miejsca zamieszkania ojca do miejsca swojego zamieszkania, jak również widzenia w co drugi weekend oraz zabieranie dzieci do siebie w czasie świąt. Kobiecie umożliwiono także zabieranie dzieci na wakacje.

Matka, sprawczyni porwania, przez długi czas nie realizowała jednak przyznanych jej uprawnień do kontaktów z dziećmi. Kobieta jako centrum swojej życiowej aktywności wybrała Wielką Brytanię, pozostawiając dwójkę dzieci w Polsce pod opieka ich ojca. Latem 2013 r. kobieta przyjechała do Polski, aby spotkać się $z$ córką i synem oraz spędzić $z$ nimi część wakacji. Poprosiła byłego męża o umożliwienie jej zabrania dzieci na wakacje do Anglii, czyli do miejsca jej stałego zamieszkania. Jako że dzieci entuzjastycznie zareagowały na ten pomysł, ojciec wyraził zgodę na realizację kontaktów w ten sposób, że była żona zabierze małoletnich do Anglii na wakacje na umówiony czas, po czym zapewni ich bezpieczny powrót do domu. Po poczynionych ustaleniach dzieci wyjechały $z$ matka do Anglii, jednak w określonym terminie kobieta nie zwróciła małoletnich pod opiekę ich ojca, dokonując tym samym ich zatrzymania.

Z zeznań stron wynikało, iż starszy syn pokrzywdzonego i sprawczyni (chłopak mający w chwili popełnienia przestępstwa 16 lat) chciał zostać w Anglii przy matce, odpowiadał mu bowiem nowo poznany styl życia za granica. Ze starszym bratem chciała pozostać również małoletnia córka stron (dziewczyna miała wówczas 14 lat). Ojciec dzieci kategorycznie jednak się temu przeciwstawił. Mimo to matka dzieci przystała na ich postulaty, zatrzymujac je pod swoja opieka w Anglii. Kobieta poczyniła nawet pierwsze kroki w celu przygotowania dla dzieci nowego środowiska życiowego, np. załatwiając przyjęcie małoletnich do angielskiej szkoły. Kobieta argumentowała, że dokonała zatrzymania dzieci na ich długotrwałe i zdecydowane prośby. 
Ojciec małoletnich, majac na uwadze, że ze względu na wiek córki to on jest wciąż powołanym do opieki nad małoletnią, przez co sprawczyni dopuściła się porwania rodzicielskiego, zainicjował postępowanie na podstawie konwencji haskiej ${ }^{10}$ i złożył stosowne dokumenty w Ministerstwie Sprawiedliwości. Ministerstwo zaś jako organ centralny rozpoczęło postępowanie i zwróciło się do angielskiego Ministerstwa Sprawiedliwości z prośba o nakazanie powrotu dzieci do Polski. Angielski sąd nakazał zwrócenie dzieci pod opiekę ich ojca, na skutek czego dzieci 29 listopada 2013 r. powróciły pod opiekę ojca.

Matkę, sprawczynię porwania rodzicielskiego, oskarżono następnie o to, że w okresie od 22 sierpnia do 30 października 2013 r. dokonała zatrzymania w Wielkiej Brytanii swojej małoletniej córki wbrew woli ojca uprawnionego do opieki nad dzieckiem. Są uznał, iż faktycznie kobieta dopuściła się porwania rodzicielskiego, jednak warunkowo umorzył postępowanie karne wobec niej na okres próby jednego roku.

$\mathrm{Na}$ wydanie tego rodzaju wyroku wpłynał bogaty materiał dowodowy zebrany $\mathrm{w}$ sprawie, wśród którego znalazła się m.in. opinia biegłych $z$ Rodzinnego Ośrodka Diagnostyczno-Konsultacyjnego w Gorzowie Wielkopolskim. W opinii tej co prawda nie zaprzeczano bezprawności zachowania matki małoletnich, lecz zwrócono uwage na fakt, że w praktyce to ona przejawiała zdolności do bardziej racjonalnych ocen zachowań dzieci i w sposób obiektywny starała się oceniać zachowania małoletnich, a w razie przekroczenia norm - mobilizować do korekty. Biegli formułujący opinię stwierdzili nawet, że wyjazd małoletnich $z$ matką do Wielkiej Brytanii byłby zgodny $z$ ich dobrem i wolą, jak również, że dostrzegaja przesłanki do zmiany orzeczenia w zakresie władzy rodzicielskiej. Choć kobieta swoim zachowaniem wyczerpała znamiona przestępstwa określonego w art. 211 k.k., to w stosunku do jej postępowania i sytuacji motywacyjnej wykazano pewne zrozumienie,

10 Konwencja dotycząca cywilnych aspektów uprowadzenia dziecka za granicę, sporządzona w Hadze dnia 25 października 1980 r., Dz.U. 1995 nr 108 poz. 528. 
zaś pobudkę jej działania w postaci realizacji próśb dzieci oceniono jako świadcząca na jej korzyść.

Inna sprawa, w której sprawca porwania rodzicielskiego była matka, została rozpoznana przez Sąd Rejonowy w Lublinie (Lublin-Zachód) w 2010 r. ${ }^{11}$ Sprawczyni w tej sprawie na co dzień żyła we Francji. Miała jedną córkę, która, wyjeżdżając na emigrację, pozostawiła pod opieka swojej matki - babci małoletniej dziewczynki. Po wyjeździe $z$ Polski sprawczyni zerwała kontakty $z$ rodzina.

Matka sprawczyni po upływie dłuższego okresu braku kontaktu ze swoją córką i jej zainteresowania losami własnego dziecka poczyniła działania na rzecz ustanowienia jej rodzina zastępczą dla wnuczki, co też się stało. Małoletnia była więc wychowywana przez swoją babcię. Po pewnym czasie matka małoletniej wróciła do Polski i chciała odnowić kontakt $z$ córka. Prawna opiekunka dziecka zgodziła się wówczas, aby kobieta zatrzymała się u niej i w ten sposób podreperowała relacje $z$ dzieckiem.

Sprawczyni chciała jednak uzyskać pozwolenie od swojej matki, aby z córka spotykać się poza domem, odbywać z nią samodzielne wyjazdy. Babcia dziecka nie godziła się na takie rozwiązania, co w konsekwencji doprowadziło do licznych sporów między babcia dziewczynki a jej matką. Sprawczyni porwania rodzicielskiego zabrała więc swoja córkę $z$ domu jej prawnej opiekunki i wywiozła na działkę rekreacyjna znajomego, gdzie ukrywała się z nią przez kilka dni.

Kobieta, która uprowadziła i zatrzymała swoje dziecko, przyznała się do zarzuconego jej czynu. Wskazywała przy tym, że jej matka utrudniała jej kontakt $z$ małoletnią córką i dlatego zabrała dziecko $z$ domu rodzinnego i udała się na działkę. Sprawczyni przyznała, iż miała świadomość obowiąku poinformowania kuratora sądowego o zabraniu swojej córki, czego jednak nie uczyniła. Kilkukrotnie podnosiła, że kocha córkę, nie chciała jej uprowadzać, lecz tylko pomieszkać $z$ dzieckiem i nadrobić stracony czas, kiedy jej nie było przy małoletniej. Kobieta przyznała się, że dziec-

$\overline{11}$ Sprawa o sygn. XV K 159/10. 
ko pozostawiła wcześniej pod opieką swojej matki, bo borykała się z uzależnieniem od alkoholu, z którego się już jednak wyleczyła.

W opisywanej sprawie sąd uznał, że okoliczności czynu i wina oskarżonej nie budzą wątpliwości. W związku $z$ tym stwierdził, że matka porwanej małoletniej jest winna popełnienia zarzucanego jej czynu wyczerpującego dyspozycję art. $211 \mathrm{k} . \mathrm{k}$. i za to, na podstawie wspomnianego art. 211 k.k. w zw. z art. 58 § 3 k.k., orzekł karę grzywny w wysokości 80 stawek dziennych, ustalając stawkę dzienna na kwotę $10 \mathrm{zł}$. Kobieta bowiem sama przyznała się do tego, że miała świadomość bezprawności swojego działania, co jednak nie odwiodło jej od pomysłu dokonania porwania rodzicielskiego.

W sprawach o porwania rodzicielskie kobiety rzadziej były sprawczyniami tego czynu - częściej to mężczyźni porywali swoje małoletnie dzieci spod ich opieki. Dlatego też należy przytoczyć wybrane sprawy obrazujące sytuacje, w których to kobiety były osobami pokrzywdzonymi zachowaniem ojca bezprawnie zabierającego swoje dziecko spod ich opieki. Jedna $z$ takich spraw została rozpoznana w Sądzie Rejonowym dla Wrocławia Śródmieścia w 2009 r. ${ }^{12} \mathrm{~W}$ sprawie tej porwania małoletniego chłopca dokonał jego ojciec, który legalnie zabrał dziecko spod opieki swojej byłej małżonki, lecz w wyznaczonym przez sąd czasie nie odprowadził małoletniego $z$ powrotem pod opiekę matki dziecka.

Sprawca opisywanego porwania rodzicielskiego nie przyznał się do popełnienia zarzucanego mu czynu i tłumaczył zaistniałą sytuację nieświadomością konsekwencji prawnych orzeczenia sąu regulującego kontakty $z$ małoletnim dzieckiem, czemu jednak są rozpoznający sprawę nie dał wiary.

Mężczyzna w lipcu 2009 r., po wcześniejszym wykonaniu telefonu do swojego syna, udał się na działkę, gdzie dziecko przebywało pod opieka matki. Sprawca chciał zrealizować ustalone przez sąd kontakty ze swoimi dziećmi, starsze potomstwo nie chciało się jednak z nim spotkać, dlatego mężczyzna zabrał tylko jedno dziecko. W toku postępowania mężczyzna wskazywał, że nie miał od razu w planach dłuższego zatrzymania pod swoją opieka dziecka,

$\overline{12}$ Sprawa o sygn. II K 1281/09. 
bowiem pomysł ten zrodził się u niego dopiero w toku realizowanego kontaktu $z$ dzieckiem.

Matka małoletniego chłopca, odnotowując fakt, że dziecko nie zostało zwrócone pod jej opiekę w wyznaczonym czasie, od razu powiadomiła policję. Następnie ojciec dziecka został poinformowany telefonicznie przez funkcjonariusza policji o zgłoszeniu uprowadzenia syna. Sprawca tłumaczył się jednak funkcjonariuszowi, że nie ma technicznej możliwości odwiezienia syna pod opiekę jego matki. Dzwonił również do matki chłopca i swojej byłej żony z propozycja dogadania się. Kobieta wskazała, aby były mąż w wyznaczonym miejscu i czasie zwrócił syna pod jej opiekę. Sprawca na to przystał i w ustalonym dniu i godzinie oraz w ustalone miejsce odprowadził dziecko. Wychodzac stamtąd, zatrzymała go jednak policja.

Sprawca opisywanego porwania rodzicielskiego, odbierając syna od matki, działał zgodnie $z$ przyznanym mu zakresem władzy rodzicielskiej, jednakże od określonej w orzeczeniu sąu godziny powrotu dziecka $z$ powrotem pod opiekę matki działał już poza tym zakresem i nie był wówczas osoba powołaną do opieki nad synem. Sąd uznał, że sprawca celowo działał w sposób bezprawny, chcąc uczynić na przekór matce małoletniego syna. Rodzice dziecka byli bowiem ze sobą skonfliktowani, ojciec chłopca nie akceptował tego, że ograniczono mu władzę rodzicielska, zaś matka małoletnich zaprzestała podporządkowywania się woli sprawcy. Matka małoletniego, mając na uwadze, że były mąż dowolnie realizuje swoje kontakty $z$ dziećmi (np. biorąc na spotkanie tylko jedno $z$ nich czy nie respektujac ustalonych godzin spotkania), nie uwierzyła w możliwość ugodowego załatwienia sprawy i dlatego od razu zwróciła się z prośba o pomoc do policji.

Sąd w opisanej sprawie uznał ojca porwanego małoletniego winnym tego, że wbrew woli matki chłopaka, która została powołana do sprawowania opieki nad nim, zatrzymał chłopca i za to na podstawie art. $211 \mathrm{k} . \mathrm{k}$. skazał go na kare pięciu miesięcy pozbawienia wolności, której to wykonanie na podstawie art. $69 \S 1$ k.k. i art. $70 \S 1 \mathrm{k} . \mathrm{k}$. warunkowo zawiesił na okres próby dwóch lat.

Inna sprawę o porwanie rodzicielskie, w której kobieta była pokrzywdzoną, rozpoznano w Sądzie Rejonowym Gdańsk-Południe 
w 2008 r. ${ }^{13}$ Pokrzywdzona w sprawie była kobieta - matka małoletniego chłopaka, sprawca zaś jej były partner i ojciec dziecka. Kobieta rozstała się $z$ mężczyzną, ponieważ stosował on wobec niej przemoc psychiczną i fizyczną oraz był uzależniony od alkoholu. Mężczyznę całkowicie pozbawiono władzy rodzicielskiej nad jego i pokrzywdzonej synem.

Sprawca porwania rodzicielskiego nie pogodził się $z$ tym, że jego była partnerka odeszła od niego i wszelkimi sposobami próbował nakłonić ja do powrotu. Mężczyzna zaczaił się na kobietę i syna podczas ich spaceru. Podszedł do nich, proszac pokrzywdzoną o rozmowę, ta się jednak nie zgodziła. Pomiędzy mężczyzną a kobietą wywiązała się kłótnia. Mężczyzna, chcąc zmusić kobietę do rozmowy, zabrał jej dziecko i oddalił się w kierunku swojego mieszkania. Kobieta pobiegła za sprawca, chciała zabrać mu dziecko, co się jej nie udało, i mężczyzna przez kilka godzin przetrzymywał małoletniego. Pokrzywdzona o zaistniałej sytuacji zawiadomiła policję.

Sąd rozpoznajacy sprawę uznał mężczyznę winnego popełnienia przestępstwa. Podkreślał, że za okoliczności obciążające przyjał brutalny sposób działania oskarżonego, a także narażenie na niebezpieczeństwo małego dziecka przez trzymanie noża w jego pobliżu. W związku $z$ tym za przestępstwo określone w art. 211 k.k. sąd skazał oskarżonego na karę sześciu miesięcy pozbawienia wolności.

\section{Podsumowanie}

Według polskich danych statystycznych policji kobiety sa znacznie rzadziej sprawczyniami przestępstw niżeli mężczyźni. Tendencja ta znajduje również odzwierciedlenie w obszarze przestępstwa porwania rodzicielskiego, które mężczyźni popełniają częściej niż kobiety. Badania aktowe autorki niniejszego opracowania pokazuja jednak, że przewaga liczbowa sprawców nad sprawczyniami nie jest znaczna.

13 Sprawa o sygn. II K 412/08. 
Opisane w artykule studia przypadków poniekąd wyjaśniaja, dlaczego liczba matek porywajacych swoje dzieci jest zbliżona do liczby ojców, którzy popełniają przedmiotowy czyn zabroniony. Porwanie rodzicielskie jest przestępstwem inspirowanym silnymi emocjami, w które uwikłane sa przeważnie trzy osoby - matka, ojciec i porwane dziecko. Relacje, które występuja pomiędzy tymi członkami rodziny, sa stanowczo silniejsze i długotrwalsze niż takie, które występuja pomiędzy przypadkowymi sprawcami i pokrzywdzonymi większości przestępstw. Na motywy zachowania przestępnego sprawcy porwania rodzicielskiego oddziałuja emocje i uczucia o charakterze rodzinnym, jak np. miłość rodzica do dziecka, przywiazanie, potrzeba kontaktu z potomkiem, bezwarunkowe poczucie odpowiedzialności i potrzeba zapewnienia bezpieczeństwa dziecku. Niewątpliwie więc zaangażowanie emocjonalne kobiet, które porywają swoje dzieci, ma silna moc oddziaływania na podejmowane przez sprawczynie decyzje o tym, ażeby zawalczyć o dziecko nawet poprzez zabranie go pod swoja opiekę w sposób wyczerpujący znamiona przestępstwa określonego w art. 211 k.k. Emocjonalne zaangażowanie i fakt, że przedmiotem bezpośredniego działania sprawcy jest jego małoletnie dziecko, wyjaśnia, dlaczego kobiety, matki dzieci, decyduja się na tak kategoryczne postępowanie jak porwanie rodzicielskie i uzasadnia niewielka różnicę pomiędzy liczbą sprawców porwania rodzicielskiego płci męskiej i żeńskiej.

\section{Bibliografia}

\section{Akty prawne}

Ustawa z dnia 6 czerwca 1997 r. - Kodeks karny, Dz.U. z 2016 r. poz. 1137.

Konwencja dotycząca cywilnych aspektów uprowadzenia dziecka za granicę, sporządzona w Hadze dnia 25 października 1980 r., Dz.U. 1995 nr 108 poz. 528 . 


\section{Sprawy sądowe}

Sąd Rejonowy dla Wrocławia Śródmieścia, sprawa o sygn. II K 1281/09.

Sąd Rejonowy Gdańsk-Południe, sprawa o sygn. II K 412/08.

Sąd Rejonowy Lublin-Zachód w Lublinie, sprawa o sygn. XV K 159/10.

Sąd Rejonowy w Gorzowie Wielkopolskim, sprawa o sygn. II K 199/14.

\section{Opracowania}

Błachut Janina, Szewczyk Maria, Wójcikiewicz Józef (red.), Nauka wobec przestępczości. Księga ku czci prof. T. Hanauska, Kraków : Wyd. Instytutu Ekspertyz Sąowych, 2001, ISBN 83-87425-60-5.

Drapała Katarzyna, Buczkowski Konrad, Porwania rodzicielskie. Analiza umorzeń $i$ odmów wszczęcia postępowania $w$ sprawach o przestępstwo $z$ art. 211 k.k., „Prawo w działaniu” 2014, t. 18, s. 105-132.

Grześkowiak Alicja, Wiak Krzysztof (red.), Prawo karne, Warszawa : C.H. Beck, 2015, ISBN 978-83-255-6129-1.

Kołakowska-Przełomiec Helena, Przestęstwa przeciwko rodzinie $i$ opiece $w$ projekcie kodeksu karnego, „Przeglad Prawa Karnego” 1995, nr 12, ISSN 0860-8903.

Marek Andrzej, Konarska-Wrzosek Violetta, Prawo karne, Warszawa : C.H. Beck, 2016, ISBN 978-83-255-8349-1.

Prawo karne materialne. Część ogólna i szczególna, red. M. Bojarski, Warszawa : Wolters Kluwer, 2015, ISBN 978-83-264-9449-9.

Stefański Ryszard Andrzej, Prawo karne materialne część szczególna, Warszawa : Difin, 2009, ISBN 978-83-7641-088-3.

\section{Zasoby internetowe}

Udział kobiet w ogólnej liczbie poszczególnych rodzajów przestępstw, $<$ http://bit.ly/2hL5QZ0>. 